\title{
PENERAPAN MODEL POE2WE DALAM MENENTUKAN AKSELERASI GRAVITASI BERBASIS SOFTWARE LOGGER PRO AND VARNIER MOTION DETECTOR
}

\author{
Dika Mahriza $^{1)}$, Nana $^{2)}$ \\ ${ }^{I}$ Mahasiswa Program Pendidikan Fisika Fakultas Keguruan dan Ilmu Pendidikan \\ Universitas Siliwangi \\ ${ }^{2}$ Dosen Program Pendidikan Fisika Fakultas Keguruan dan Ilmu Pendidikan \\ Universitas Siliwangi \\ Jln. Siliwangi No.24 Tasikmalaya \\ E-mail : $\underline{\text { dikunmz0511@ @mail.com }}^{1)}$
}

\begin{abstract}
Penelitian ini merupakan bentuk penerapan model POE2WE dalam sebuah percobaan berbasis software logger pro and varnier motion detector. Penelitian ini bertujuan untuk mengetahui cocok atau tidaknya penerapan model POE2WE dalam menentukan akselerasi gravitasi dengan bantuan software logger pro dan vernier motion detector. Penelitian ini menggunakan metode desktiptif dengan pendekatan kualitatif berdasarkan hasil studi pustaka dan menggunakan model POE2WE yang meliputi (Prediction, Observation, Explanation, Elaboration, Write and Evaluation). Topik yang dipilih pada penelitian ini yaitu Gerak Lurus Berubah Beratura (GLBB), Hukum II Newton dan Bidang Miring. Pada penelitian ini subjeknya adalah software logger pro dan vernier dan objeknya adalah nilai akselerasi gravitasi. Kegiatan penelitian ditinjau dari hukum II Newton yang berbasis microcomputer based laboratory pada bidang miring. Suatu benda yang diletakkan pada bidang miring akan meluncur dengan kecepatan tertentu akibat sudut yang berbeda-beda. Pergerakkan benda tersebut dihubungkan dengan Interface LabQuest Mini dan laptop. Kemudian data yang diperoleh akan dikelola dengan software logger pro dan vernier motion detector sehingga menghasilkan nilai akselerasi gravitasi dari benda tersebut.Hasil penelitian ini bahwa penerapan model POE2WE cocok digunakan dalam percobaan menetukan akselerasi gravitasi yang di kombinasi dengan software logger pro and varnier motion detector data percobaan akan dihasilkan lebih akrat dan nilai ralat akan lebih kecil.
\end{abstract}

Key words: Model POE2WE, Akselerasi Gravitasi, Software Logger Pro dan Vernier Motion Detector.

\begin{abstract}
Abstrak - This research is a form of application of the POE2WE model in an experiment based on logger pro and varnier motion detector software. This study aims to determine whether or not the application of the POE2WE model is suitable in determining gravity acceleration with the help of logger pro software and vernier motion detector. This research uses descriptive method with a qualitative approach based on the results of library studies and using the POE2WE model which includes (Prediction, Observation, Explanation, Elaboration, Write and Evaluation). The topics chosen for this research are Straight Changing Irregular Motion (GLBB), Newton's Second Law and the Leaning Field. In this research the subject is pro and vernier logger software and the object is the gravity acceleration value. Research activities are reviewed from Newton's second law based on microcomputer based laboratory in the incline. An object placed on an incline will glide at a certain speed due to different angles. The movement of the object is connected to the LabQuest Mini Interface and laptop. Then the data obtained will be managed by logger pro software and vernier motion detector so as to produce the value of gravity acceleration of the object. The results of this study that the application of the POE2WE model is suitable for use in experiments determining the gravity acceleration in combination with the pro logger and varnier motion detector software experimental data will produce more akrat and the value of errata will be smaller.
\end{abstract}

Kata kunci: Model POE2WE, Gravity Acceleration, Software Logger Pro and Vernier Motion Detector. 


\section{PENDAHULUAN}

Di dalam pembelajaran fisika tidak hanya penyampaian materi dan konsep saja namun tetap harus melibatkan kegiatan yang mampu membuktikan konsep yang diperoleh seperti kegiatan praktikum berupa percobaan.

Jika ditinjau dari perkembangan ilmu pengetahuan dan teknologi yang sangat pesat sehingga mampu mengembangkan berbagai unsur-unsur pembelajaran. Salah satu unsur tersebut yaitu model pembelajaran seperti model POE2WE yang meliputi enam langkah yaitu Prediction, Observation, Explanation, Elaboration Write And Evaluation dan media pembelajaran berbasis microcomputer based laboratory seperti software logger pro dan vernier motion detector dapat digunakan untuk melakukan percobaan mencari nilai akselerasi gravitasi dari gerak benda pada bidang miring.

Menurut Lesnan dan Yusnia (2014) gerak pada bidang miring adalah gerak benda dengan keadaan lintasan yang lurus pada bidang miring. Bidang miring yaitu suatu permukaan datar yang memiliki suatu sudut, yang bukan sudut tegak lurus terhadap permukaan horizontal. Dari keadaan tersebut, banyak sekali gaya-gaya yang bekerja sehingga konsep persamaan hukum II Newton dapat digunakan untuk mendeskripsikan gaya-gaya tersebut sekaligus mengetahui persamaan akselerasi gravitasi yang dapat digunakan pada percobaan.

Menurut Eka, Hufri, dkk (2016) dalam Satriawan (2012) setiap benda mempunyai gaya yang dinamakan dengan gaya berat. Berat adalah gaya tarik bumi tergadap benda tersebut atau hasil kali massa dengan percepatan gravitasi bumi. Berbeda dengan massa benda yang tetap, gaya berat benda selalu berubah-ubah tergantung dengan besar percepatan gravitasi yang ada di tempat tesebut. Percepatan bumi yang disimbolkan dengan ' $g$ ' menunjukkan rata-rata percepatan yang dihasilkan medan gravitasi pada permukaan bumi dengan satuan $\mathrm{m} / \mathrm{s}^{2}$.

Menuru Lesnan dan Yusnia (2014) dalam Daryono (1992 : 15) dalam akselerasi gravitasi setiap tempat akan berbeda nilainya, contoh di daerah kutub akselerasi gravitasi $9,83 \mathrm{~m} / \mathrm{s}^{2}$ sedangkan di daerah equator akselerasi gravitasinya sekitar $9,78 \mathrm{~m} / \mathrm{s}^{2}$. Perbedaan tersebut dipengaruhi tiga faktor, (1) bentuk bumi yang elips atau pepat menyebabkan gaya sentripental menentang gravitasi di equator ke pusat bumi sehingga nilai akselerasi gravitasi bumi di equator lebih kecil dari pada di kutub. (2) bervariasinya topografi permukaan bumi mengahasilkan akselerasi gravitasi karena akselerasi gravitasi bergantung pada jaraknya terhadap permukaan bumi. Dimana semakin jauh sebuah benda dari permukaan bumi maka akselerasinya akan semakin kecil begitupun sebaliknya semkain dekat benda dengan permukaan bumi akselerasi gravitasinya semakin besar. (3) kepadatan atau kerapatan massa bumi yang berbedabeda mengahsilkan akselerasi gravitasi. Dimana semakin padat atau rapat massa bumi maka makin kecil gravitasinya. Daratan 
merupakan wilayah yang memiliki kerapatan masa yang tinggi sehingga gravitasinya lebih kecil dari pada wilayah lautan.

Dari pembahasan dapat disimpulkan bahwa nilai $g$ dapat dicari salah satunya menggunakan metode gerak benda pada bidang miring yang ditinjau dari persamaan hukum II Newton dengan menggunakan model POE2WE dan software logger pro dan vernier motion detector.

\section{LANDASAN TEORI}

Gerak Lurus Berubah Beraturan (GLBB)

GLBB adalah gerak suatu benda dalam lintasan lurus dengan percepatan tetap. Artinya, setiap selang waktu yang sama, perubahan kecepatan benda tetap. GLBB dibedakan menjadi dua yaitu GLLB dipercepat dan di perlambat. (Ni Ketut Lasmi, 2008 : 19) Persamaan GLBB yang menggunakan jarak sebagai fungsi waktu :

$$
X(t)=X_{0}+v_{0}+\frac{1}{2} \alpha t^{2}
$$

\section{Hukum II Newton}

Hukum II Nweton dapat disimpulkan bahwa besarnya gaya yang dialami benda sebanding dengan massa benda dan percepatan benda. Persamaan hukum II Nweton :

$$
F=m \alpha
$$

Konsep ini terdapat dalam percobaan gerak benda pada suatu bidang miring yaitu benda akan mengalami percepatan jika benda menerima gaya total dari luar dan arah percepatan tersebut searah dengan total gaya.

$$
\Sigma F=m \alpha
$$

Bidang miring yaitu suatu permukaan datar yang memiliki suatu sudut, yang bukan sudut tegak lurus terhadap permukaan horizontal. Benda yang berada di atas bidang miring, arah geraknya mengikui bidang miring. Arah miring ini dianggap sebagai sumbu $\mathrm{x}$, sedangkan pada sumbu y yang tegak lurus bidang tidak terjadi perpindahan.

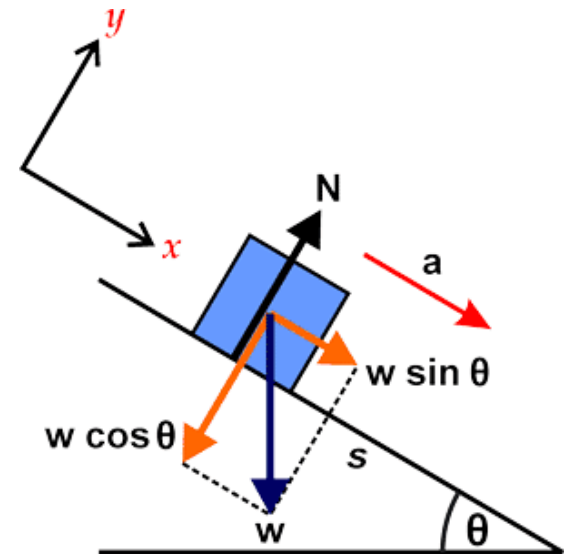

Gambar 1.Sebuah balok yang diletakkan di sebuah bidang miring dengan sudut kemiringan $\theta$.

$\Sigma F_{y}=0$

$N-\mathrm{w} \cos \theta=0$

$N=\mathrm{w} \cos \theta$ atau $N=\mathrm{mg} \cos \theta$

$\Sigma F_{x}=m . \mathrm{a}$

$\mathrm{W} \sin \theta=\mathrm{m}$. a

m.g $\sin \theta=\mathrm{m} . \mathrm{a}$

$\mathrm{g} \sin \theta=\mathrm{a}$

\section{METODE PENELITIAN}

Pada penelitian ini menggunakan metode deskriptif untuk mendeskripsikan dan menganalisis penggunaan model POE2WE dalam menentukan akselerasi berbasis software logger pro dan vernier motion detector. Teknik pengumpulan data yang digunakan adalah dengan studi pustaka. 
Menurut Abdi Mirzaqon T (2017) dalam Mardalis (1999) Studi kepustakaan adalah metode yang digunakan untuk mengumpulkan informasi dan data dengan bantuan berbagai macam material yang ada di perpustakaan seperti dokumen, buku, majalah, kisah-kisah sejarah, dsb.

Selain itu, menurut Abdi Mirzaqon T (2017) dalam Sugiono (2012) dalam studi kepustakaan merupakan kajian teoritis, referensi serta literatur ilmiah lainnya yang berkaitan dengan budaya, nilai dan norma yang berkembang pada situasi sosial yang diteliti.

Teknik pengumpulan data yaitu teknik dokumentasi. Menurut Abdi Mirzaqon T (2017) dalam Arikunto (2010) dokumentasi adalah mencari data mengenai hal-hal atau variable yang berupa catatan, buku, makalah atau artikel, jurnal dan sebagainya.

Menurut Lesnan dan Yusnia (2014), alat dan bahan pada percobaan mencari nilai akselerasi gravitasi dengan menggunakan software logger pro dan vernier motion detector yaitu : 1) Laptop, 2) Balok Pengganjal, 3) Logger Pro, 4) Kereta, 5) Motion Detector, 6) Vernier Dynamic Track, 7) Pengait Sensor Gerak, 8) Vernier DataCollection Interface, 9) Mistar. Kemudian Prosedur percobaan yang dilakukan adalah : 1) Menghubungkan sensor gerak ke interface yang tersambung ke laptop, 2) Memasang sensor gerak ke pengait yang terdapat diujung track,3) Mengangkat bagain ujung track yang terdapat sensor gerak, kemudian mengganjalnya dengan balok, 4) Memasang papan luncur (bidang miring) dan meletakkan kereta yang sudah dihubungkan dengan ticker time di atasnya sambil dihitung ketinggian bidang miring dengan menggunakan mistar, 5) Melepaskan kereta dan membiarkannya bergerak turun di sepanjang bidang miring samapi memantul, 6) Mengukur waktu tempuh kereta dengan software looger pro menggunakan laptop, 7) Melakukan pengulangan kembali langkah di atas sebanyak sepuluh kali, 8) Menulis data dalam tabel.

\section{HASIL DAN PEMBAHASAN}

\section{A. Hasil Penelitian}

Menurut Irnin Dwi A ( 2016 : 115 ) Pengukuran nilai percepatan gravitasi bumi (g) dapat diukur dengan berbagai metode. Pada umumnya penentuan percepatan gravitasi bumi ditentukan dengan alat sederhana yaitu ayunan bandul, tetapi analisis yang dilakukan membutuhkan waktu yang lama. Oleh karena itu dibutuhkan analisis yang tepat dan cepat dengan menggunakan bantuan software logger pro. Pada eksperimen ini peneliti menentukan nilai percepatan gravitasi bumi dengan cara yang sederhana tetapi membutuhkan waktu yang cepat dan akurat untuk menganalisis datanya yaitu dengan cara meluncurkan sebuah mobilmobilan di atas lintasan yang licin pada bidang miring dengan bantuan perangkat microcomputer based laboratory (MBL). Penelitian dengan berbantuan MBL dan software logger pro akan mempermudah dalam analisis data yang cepat dan tepat. 
Nana (2014) dalam Nana (2014 : 56-57) model POE2WE dikembangkan dari model POEW dan model pembelajaran Fisika dengan pendekatan Konstruktivistik. Model POE2WE merupakan model yang dikembangkan untuk mengetahui pemahaman peserta didik mengenai suatu konsep dengan pendekatan Konstruktivistik, dengan begitu peserta didik mempunyai peluang dalam membangun berbagai pengetahuan, mengkomunikasikan pemikiran, dan menuliskan hasil diskusi sehinnga lebih menguasai dan memahami konsep.

Menurut Nana (2014) dalam Permatasari (2011 : 1) bahwa melalu model ini, peserta didik mendapat kesempatan untuk membangun pengetahuannya, melakukan pengamatan terhadap fenomena serta mengkomunikasikan pemikiran dan hasil diskusi sehingga akan lebih mudah menguasai konsep yang diajarkan.

Selain itu, menurut Nana (2014) Model POE2WE memiliki 6 langkah yaitu : pertama prediction merupakan tahap di mana peserta didik membuat prediksi atau dugaan awal terhadap suatu permasalahan dari pertanyaan, gambar, video bahkan fenomena, dsb. Kedua observation yaitu tahap untuk membuktikan prediksi dengan eksperimen yang dilakukan peserta didik. Ketiga explanation yaitu tahap di mana peserta didik memberikan penjelasan terhadap hasil eksperimen yang telah dilakukan. Keempat elaboration merupakan tahap di mana peserta didik membuat contoh atau menerapkan dalam kehidpuan sehari- hari. Kelima write atau menulis dilakukan dengan melakukan komunikasi secara tertulis, merefleksikan pengetahuan dan gagasan yang dimiliki perserta didik.keenam evaluation yaitu tahap di mana evaluasi terhadap pengetahuan, keterampilan dan perubahan proses berpikir.

Berdasarkan tanggapan siswa terhadap model POE2WE dalam pembelajaran, yaitu 1) Berdasarkan tes yang dilakukan terhadap 15 siswa yaitu dengan cara memberikan soal kepada siswa pada saat setelah pembelajaran mengenai materi pokok metode ilmiah didapat rata-rata presentase hasil belajar siswa yaitu 90\%, dimana itu termasuk kategori sangat baik. Dari presentase tidak ada siswa yang mendapatkan nilai dengan kategori kurang baik. 2) Berdasarkan angket yang telah diberikan kepada 15 siswa didapat ratarata skor respon ketertarikan siswa terhadap pembelajaran yaitu sebesar 74,67. Rata-rata skor respon siswa terhadap kemudahan dalam memahami dan mempelajari materi yaitu sebesar 83,3. Rata-rata skor respon siswa dalam keaktifan dan keberanian mengungkapkan pendapat pada proses pembelajaran yaitu sebesar 73,3. Dan ratarata skor memuat tanggapan kemudahan siswa dalam menyimpulkan kegiatan pembelajaran yaitu sebesar 83,3.

Berdasarkan eksperimen yang dilakukan Lesnan dan Yusnia Hendia (2014), data yang diperoleh sebagai berikut : 


\begin{tabular}{cccc}
\hline No. & $\mathrm{y}(\mathrm{cm})$ & $\mathrm{I}(\mathrm{cm})$ & $\mathrm{a}\left(\mathrm{m} / \mathrm{s}^{2}\right)$ \\
\hline $\mathrm{I}$ & 6.3 & I2I.7 & $0.43 \mathrm{I} 3$ \\
2 & 6.7 & I2I.7 & 0.4643 \\
3 & $7 . \mathrm{I}$ & I2I.7 & $0.48 \mathrm{I} 2$ \\
4 & 7.5 & I2I.7 & 0.5065 \\
5 & 7.9 & I2I.7 & 0.5373 \\
6 & 8.3 & I2I.7 & $0.564 \mathrm{I}$ \\
7 & 8.7 & I2I.7 & 0.6192 \\
8 & 9.1 & I2I.7 & 0.6472 \\
9 & 9.5 & I2I.7 & 0.6867 \\
I0 & 9.9 & I2I.7 & 0.6958 \\
\hline \hline
\end{tabular}

Gambar 2. Tabel Data Eksperimen

Di mana grafik linear yang menunjukkan hubungan $\alpha$ dan $\sin \theta$ pada gambar 4 . Kemudian dari data tersebut kami menggunakan persamaan (4). Hasil perhitungan dapat di lihat pada gambar 3 .

\begin{tabular}{cccc}
\hline No. & $\sin \Theta$ & $\mathrm{a}\left(\mathrm{m} / \mathrm{s}^{2}\right)$ & $\mathrm{g}\left(\mathrm{m} / \mathrm{s}^{2}\right)$ \\
\hline I & 6.3 & $0.43 \mathrm{I} 3$ & $8.33 \mathrm{I} 62$ \\
2 & 6.7 & 0.4643 & 8.43364 \\
3 & $7 . \mathrm{I}$ & $0.48 \mathrm{I} 2$ & $8.248 \mathrm{I} 7$ \\
4 & 7.5 & 0.5065 & $8.2 \mathrm{I} 88 \mathrm{I}$ \\
5 & 7.9 & 0.5373 & $8.277 \mathrm{I} 4$ \\
6 & 8.3 & $0.564 \mathrm{I}$ & $8.27 \mathrm{I} 20$ \\
7 & 8.7 & $0.6 \mathrm{I} 92$ & $8.66 \mathrm{I} 68$ \\
8 & $9 . \mathrm{I}$ & 0.6472 & $8.6554 \mathrm{I}$ \\
9 & 9.5 & 0.6867 & 8.79699 \\
I0 & 9.9 & 0.6958 & 8.55342 \\
& Rata-rata & & $8.4448 \mathrm{I}$ \\
\hline
\end{tabular}

Gambar 3. Tabel Perhitungan Nilai g

Dengan menghitung data percobaan di dapat nilai gravitasi sebesar $g=8,444481$ $\mathrm{m} / \mathrm{s}^{2=}$. Data nilai keakuratan datasebesar 85,71 $\%$. Suatu benda pada bidang miring bergerak karena dipengaruhi oleh akselerasi gravitasi. Semakin besar sudut kemiringan bidang maka semakin besar akselerasi benda. Dan semakin kecil sudut kemiringan, maka semakin kecil pula akselerasi benda.

Data hasil perhitungan didapatkan nilai gravitasi sebesar $g=9,78 \mathrm{~m} / \mathrm{s}^{2}$ dan tetapan gravitasi $g=9,78 \mathrm{~m} / \mathrm{s}^{2}$. Nilai ke akuratan pada pada perhitungan adalah sebesar $85,71 \%$.
Pada nilai perhitungan di atas dapat dinyatakan cukup baik walaupun masih terdapat perbedaan yang dikarenakan faktor akselerasi gravitasi tergantung dari jaraknya terhadap permukaan bumi dan hal ini dikarenakan sudut terllau kecil (mendektai nol). Serta pengaruh gaya gesek yang dialami benda.

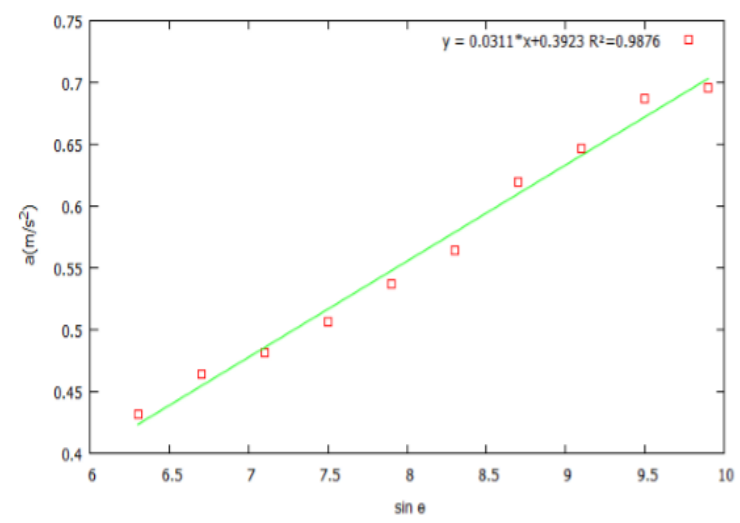

Gambar 4. Grafik Linear

Lesnan dan Yusnia (2014) menyimpulkan hasil percobaanya bahwa jarak antara setiap ketingggian yang bertambah menunjukkan bahwa kereta yang diluncurkan di atas bidang miring melakukan gerakan GLBB dipercepat. Dan hasil perhitungan yang didapatkan nilai akselerasi gravitasi sebesar $g$ $=8,44481 \mathrm{~m} / \mathrm{s}^{2}$ dan tetapan gravitasi sebesar $g$ $=9,8 \mathrm{~m} / \mathrm{s}^{2}$ di sini terlihat perbedaan yang tidak signifikan dengan nilai tingkat keakuratan data adalah sebesar $85,71 \%$. Penyebab hal ini dikarenakan sudut $\theta$ yang terlalu kecil (mendektai nol). Serta pengaruh gaya gesek yang dialami benda.

\section{B. Pembahasan}

Hasil analisa respon siswa terhadap pembelajaran dengan model POE2WE menunjukkan persentase rata-rata secara keseluruhan termasuk dalam kategori sangat 
baik. Hal ini menunjukkan bahwa pembelajaran Fisika dengan model POE2WE mendapat respon positif dari siswa. Proses pembelajaran menggunakan model ini dapat meningkatkan kemampuan siswa dalam keterampilan proses Fisika, meningkatkan keberanian siswa dalam mengungkapkan pendapat, ide, dan gagasan serta meningkatkan keaktifan siswa dalam proses pembelajaran. Pada data hasil respon siswa juga terlihat seluruh aspek masuk dalam kategori sangat baik.

Begitupun pada percobaan, keenam langkah pada model POE2WE yang terstruktur dapat digunakan pada percobaan mencari akselerasi gravitasi, Dengan rangkaian kegiatan sebagai berikut : 1) Prediction, Peserta didik menyiapkan alat dan bahan serta membuat hipotesis. 2) Observation, peserta didik membuktikan hipotesis dengan melakukan percobaan, 3) Explanation, peserta didik berdiskusi sesama teman kelompok untuk menjelaskan hasil percobaan, 4) Elaboration, peserta didik menghubungkan percobaan yang sedang dilakukan dengan berbagai topik sebagai bahan tinjauan dan menghubungkannya dengan kehidupan sehari-hari. 5) Write, peserta didik membuat laporan dalam bentuk tulisan, 6) Evaluation, peserta didik mendemonstrasikan hasil percobaan.

Penggunaan model POE2WE tidak mempengaruhi hasil percobaan. Namun, akan mempengaruhi cara-cara percobaan saja karena dengan model POE2WE kegiatan percobaan akan lebih terstruktur.

\section{PENUTUP}

\section{A. Kesimpulan}

Berdasarkan data yang diperoleh bahwa nilai gravitasi dari percobaan menggunakan software logger pro and vernier motion detector yaitu sebesar $\mathrm{g}=8,44481$ dengan nilai ralat sebesar 0,000431 dan berdasarkan respond siswa terhadap perkembangan model POE2WE yang diterapkan dalam pembelajaran sangat baik dan adanya kejelasan struktur dari model POE2WE cocok digunakan dalam melakukan percobaan mencari akselerasi gravitasi berbasis microcomputer basel laboratory dengan bantuan software logger pro and vernier motion detector. Hanya saja model ini tidak akan mempengaruhi hasil percobaan, namun mempengaruhi langkah-langkah dari kegiatan percobaan tersebut.

\section{B. Saran}

Berdasarkan pembahasan yang telah dipaparkan sebagai saran : 1) memiliki persiapan lebih dalam menyediakan sumber literatur seperti jurnal, makalah, artikel sehingga pembahasan teoritis dan data yang diperoleh lebih relevan dan mendalam, 2) mempersiapakan fisik dan mental karena dalam studi kepustakaan kegiatan lebih banyak duduk di depan layar yang membuat mata dan badan terasa lebih lelah.

\section{UCAPAN TERIMA KASIH}

Saya mengucapkan terima kasih kepada Dosen Pengampu Fisika Sekolah II yang 
bernama bapak Dr. Nana,.M.Pd atas bimbingannya sehingga tugas ini selesai dikerjakan.

\section{PUSTAKA}

Abdi M T. (2017). Studi Kepustakaan Mengenai Landasan Terori dan Praktik Konseling Expressive Writing . hl 3-4.[Online]. Tersedia : https://media.neliti.com /media/publication/253525-studikepustakaan-mengenai-landasan-teorc084d5fa.pdf . [15 Februari 2020].

Daryono. (1992). Penentuan Koefesien Momen Inersia Pada Bidang Miring, 14-15.

Eka P R, Hufri, Zulhendri K. (2016). Pembuatan Alat Penentuan Percepatan Gravitasi Bumi Menggunakan Metode Pendulum Berbasis Sensor Cahaya LDR. Pillar Of Physics.Vol. 8 : 33.[Online]. Tersedia http://ejournal.unp.ac.id/students/inde x.php/artcle/download/2488/1988.[15 Fevruari 2020].

Irnin. (2016). Pengembangan Alat Eksperimen Penentuan Percepatan Gravitasi Bumi Berdasarkan Teori Bidang Miring Berbasis Microcomputer Based Laboratory (MBL). Pengembangan Alat Eksperimen Penentuan. 9 (2) : 115. [Online]. Tersedia : https://journal.lppmunindra.ac.id. [16 Februari 2020].

Lasmi Ketut N. (2008). Seri Pendalaman Materi Fisika untuk SMA/MA Siap Tuntas Menghadapi UN. hl : 19. Jakarta : Penerbit Erlangga.

Lesnan, Yusnia H. (2014). Penentuan Percepatan Gravitasi dengan Metode Gerak pada Bidang Miring
Menggunakan Software Logger Pro. Penentuan Percepatan Gravitasi dengan Metode.[Online]. Tersedia : http://docshare01.docshare.tips/files/2 5104/251040758.pdf. [15 Februari 2020].

Nana, Sajidan, Akhyar, M., \& Rochsantiningsih, D. (2014). Pengembangan Pembelajaran EWE dalam Kurikulum 2013. Seminar Nasional Pendidikan Sains. [Online]. Tersedia : https : jurnal.fkip.uns.ac.id/index.php/snps/a rticle/view/4944. [10 Februari 2020].

Nana, sajidan, Akhyar, M., \& Rochsantiningsih, D. (2014). The Development Of Predict, Observe, Explain, Elaborate, Write, and Evaluation (Poe2we) Learning Model in Physics Learning At Senior Secondary School. Journal of Education and Practie. 5 (19) : 5657. [Onilne]. Tersedia : https://pdfs.semanticscholar.od4537d 64151743c19f76ddc81f5040255a9.pd f. [16 Februari 2020].

Satriawan, Mirza. (2012). Fisika Dasar. Jakarta : Book. 